\title{
ACTIVE WORK PARTICIPATION OF THE CZECH ELDERLY
}

\author{
Lea Kubíčková, Vladimír Hajko², Martina Rašticová3, Nad'a Hazuchová ${ }^{1}$ \\ ${ }^{1}$ Department of Marketing and Trade, Faculty of Business and Economics, Mendel University in Brno, \\ Zemědělská 1, 61300 Brno, Czech Republic \\ ${ }^{2}$ Department of Business Economics, Faculty of Business and Economics, Mendel University in Brno,Zemědělská 1 , \\ 61300 Brno, Czech Republic \\ ${ }^{3}$ Department of Law and Humanities, Faculty of Business and Economics, Mendel Universityin Brno,Zemědělská 1 , \\ 61300 Brno, Czech Republic
}

To cite this article:KUBÍČKOVÁLEA,HAJKOVLADIMÍR, RAŠTICOVÁMARTINA,HAZUCHOVÁ NAĎA. 2018. Active Work Participation of the Czech Elderly. Acta Universitatis Agriculturae et Silviculturae Mendelianae Brunensis, 66(5): 1287-1293.

To link to this article: https://doi.org/10.11118/actaun201866051287

\begin{abstract}
Majority of developed countries exhibit changing transition towards older population structure. This explains why nowadays, the so-called active ageing - a policy focus to help people remain in charge of their own lives as they age and to promote their continuing contribution to the economy and society - is so frequently discussed. In the context of active ageing, active work participation of elderly is one of the prospective policy objectives, along with the identification of the motives of elderly to stay on the job market. Existing literature indicates that a large number of factors influence this decision, including income and living conditions, whether the person lives alone or not, health condition, social contacts, place of residence, but also varied interventions based on local or national government policies. Empirical results however remain scarce. This article provides insights into what influences the decision of the elderly to remain on the job market in the Czech Republic.
\end{abstract}

Keywords: elderly, seniors, active work participation, logit, motives

\section{INTRODUCTION}

This article utilizes survey data to identify the factors influencing the decisions of the Czech elderly regarding their job market participation.

Old age is natural part of human life, necessarily linked to previous phases of childhood, youth and adulthood periods, often without very sharp boundaries between them. It is sometimes labeled as the last stage of human human ontogeny. Čevela et al. (2012) define old age as the last the last stage of the development of human life. Mühlpacher (2004) defines old age as a consequence and manifestation of genetically conditioned involutive processes, further influenced by factors experienced throughout lifetime such as illness or lifestyle, and with social role changes. Haškovcová (1989) argues that old age is closely tied to social customs, with economic factors being among the main causes. Old person is defined as a person entitled to (old age) retirement payments. The retirement (or job market exit) is therefore often viewed as the start of the old age phase. Mühlpacher (2004) highlights that retirement age is advancing with the procedural demographic changes towards the age of 65 . OECD (2015) estimates that people aged 60 and above will reach 2.4 billion by 2050. Börsch-Supan et al. (2013) state that while ageing is obvious, much less is known about its consequences and effects 
or the chances to influence those by the means of public policies.

WHO(2002) argues that elderly should be entitled to participate on the job markets according to their individual needs and abilities. This issue is the main concern of the so-called Age Management - in particular regarding the creation of work conditons that are sutiable for job participation of the elderly (Novotný et al., 2014).

Due to the changes in demographic structure, the so-called active ageing is frequently discussed in all developed countries. Walker (2002) considers active ageingas multidimensional strategy connecting both individual and social interests. Similarly. Holczerová and Dvořáčková (2013) define four dimensions that influence activity in the old age-social environment, personal individuality, health condition and a range of opportunities. WHO (2002) argues that active ageing should not be limited to job market participation, but should extend into active participation on social, economic, cultural, spiritual and civic activates. Martin et al. (2015) stress that successful ageing, closely tied with active ageing, can be understood quite differently in different cultures. For instance, Eastern countries associate pleasant ageing with open family and social relationships and tolerance. Western countries, for instance represented by the United States, consider public engagement and vitality as signs of successful ageing. Vágnerová (2007) argues that a change in social importance of person, a transition from individuality to anonymous crowd of the elderly is associated with retirement. In a similar fashion, Křivohlavý (2011) argues that retirement is a radical change that affects the persons's life and is usually tied with balancing and evaluation of one's life as overall success or failure, often accompanied with the change in person's identity and abandonment of frequently familiar colleagues. Vidovićová (2005) considers the retirement defined by chronological age as a form of ageism and as such, considers it a barrier for job market participation.

Other reasons for the elderly to consider active age prolongation, besides the financial incentives, are the need to view oneself as useful, a chance to participate in the society, and the effort not to lose social contacts (see e.g. Tickle, 2008; Bradley, 2004 or Pisarev, 2006). Barnes et al. (2004) also highlight the influence of the job description, authority and respect associated with the given job, as well as fear of boredom and non-fulfilment.

Among the important focus areas is active work participation of elderly. Comparatively low participation of the elderly on the job market may be caused by variety of factors, among some frequently debated are inadequate or outdate human capital characteristics and insufficient public policy incentives.

This relatively low frequency of active work participation might be associated with a number of negative socioeconomic effects, as well as with negative influence on the economic growth and inefficient use of scarce resources and human capital investments. Reflecting upon demographic trends and sustainability of pension fund schemes, active work participation is highly desirable. As such it was promoted in The Lisbon Strategy, and in 2001, Stockholm saw a direct formulation of an objective to increase the work participation of people aged $55-64$ up to $50 \%$ by 2010 in the European Union. European Comission (2015) identified healthy and active ageing as one of the main challenges for all member countries, as well as an area where Europe can achieve a headship with innovative solutions. In the framework of European Innovation Partnership on Active and Healthy Ageing and with response to population ageing both in EU and worldwide, and in effort to generate new business opportunities, three main goals were put up: 1) to improve the health and quality of life of Europeans with a focus on older people; 2) to support the long-term sustainability and efficiency of health and social care systems; 3 ) to enhance the competitiveness of EU industry through business and expansion in new markets.

Active ageing concept has roots in the observed trend of population ageing and its (largely negative) effect on public finance. A number of studies was conducted with focus on population ageing effects on labor force or physical activity. Economic effects are mainly tied with increased public spending on transfer payments (in particular with PAYG pension systems) but also with increased healthcare expenses (again associated with public health care systems).

These increased costs motivate the effort to prolong active work age period as well as physical activity with positive health consequences (Boudiny, 2013). Similar conclusion can be found in Holmerová et al. (2006), who also add that besides social systems' sustainability the issues of people who require assistance (by family, friends or professional services) due to deteriorating health and self-sufficiency need to be taken into the account.

In order to facilitate the job market participation, it is important to find out what factors motivate the elderly to remain on the job market. Existing studies suggest that this decision is influenced by a large number of factors, such as income and living conditions, health, social relationships, residency, housing type, intervention polices, whether the senior lives alone, and likely many others. A necessary requirement for complex strategy facilitating the economic activity of the elderly is also tied to pension and taxing schemes. While the active ageing strategies do not seek to maximize labor force, they can be influential for financial sustainability and reliability of pension systems to provide the adequate payments. Pension schemes need to allow for the broad range of opportunities and methods of transition from active work age and retirement and should create neither incentives 
I: Variable names and encoding

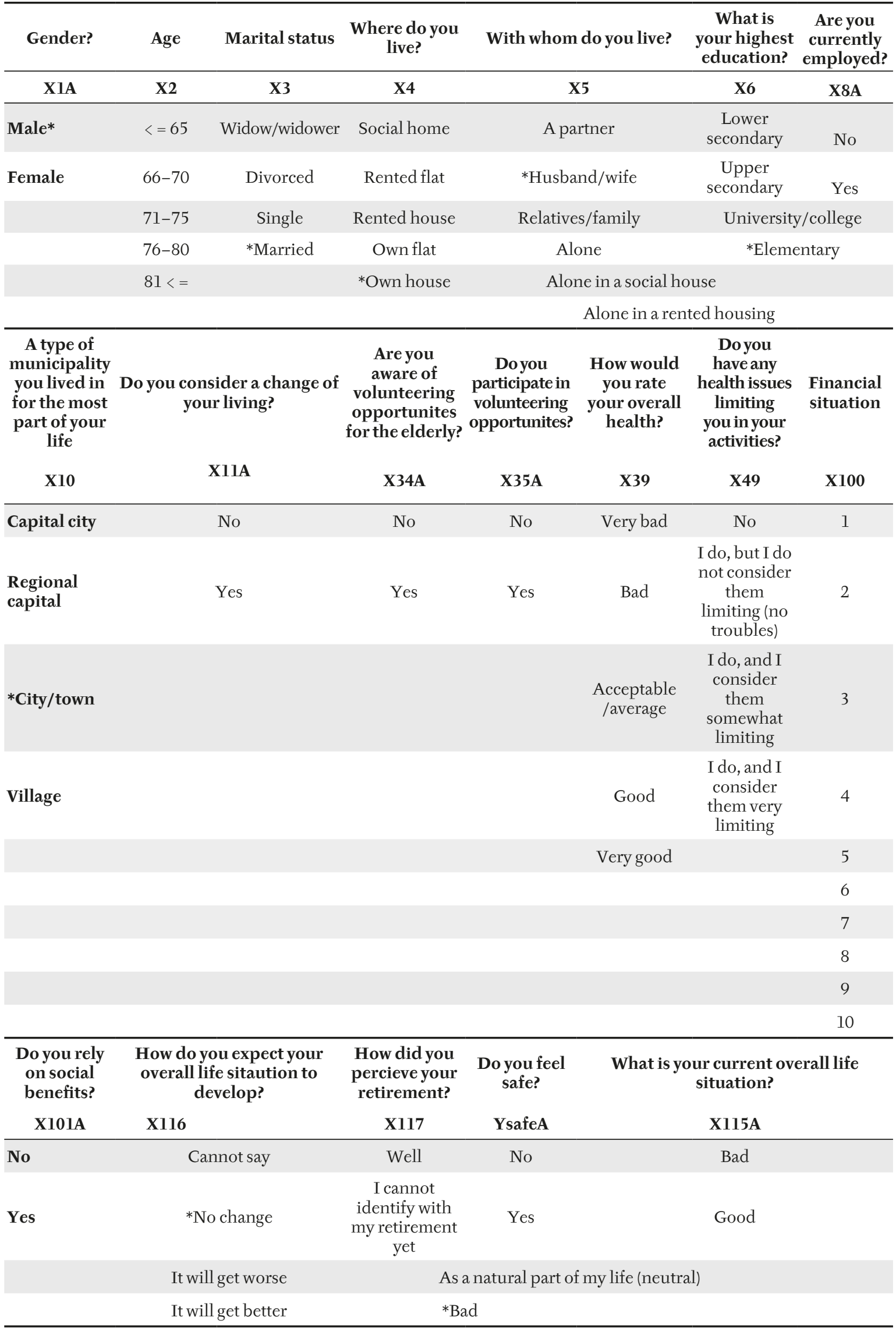


to premature job market exit nor erect barriers for economic activity of the seniors. Therefore, the main objective of this text is to identify important factors influencing the decisions of Czech seniors to stay in the labor market.

\section{MATERIALS AND METHODS}

The data is based on the survey conducted in 2016. This survey was a part of Technology Agency of the Czech Republic, project No. TB05MPSV004 - Research in the quality of life of seniors in the Czech Republic ("Výzkum v oblasti kvality života seniorů v ČR").

In total, 3071 complete survey responses were recorded. Original survey contained over 100 questions, 19 of those were appropriate for this analysis. Over $71 \%$ of survey participants indicated they are retired and do not participate on the job market anymore. 63.6\% survey respondents were female. All survey respondents were aged 55 and above. The most frequent age group was 66-70 (39.4\%), nearly a third of respondents were aged $55-65$, about $18 \%$ were $71-75$, approx. $10 \%$ were above 76 and approx. $3 \%$ were aged 81 or above.

We use three types of variables, categorical multilevel factors (X3, X4, X5, X6, X10, X116, X117), binary factors (labelled as X1, X8, X11, X34, X35, $\mathrm{X} 101$, Ysafe, $\mathrm{X} 115$; these are regarded as dummy variables with traditional $0 / 1$ representation of false/true or no/yes answers) and ordinal factors (variables labelled X2, X39, X49, X100). To allow for meaningful estimation, multi-level factors were exploded into individual categories represented as dummy variables, with suffix indicating numerical value of the original factor, their coefficients are thus representing the difference compared to the base value. E.g. X117val2 therefore represents a dummy with value of 1 in case of $\mathrm{X} 117=2$ and 0 otherwise. The default base values are indicated in the subsequent Tab. by asterisks.

To identify the influential factors of job market participation in the examined group, binomial logistic regression model was used. This model is based on Maximum Likelihood, ML, with several attractive properties such as consistency, asymptotic normality and efficiency with high number of observations. The main variable of interest is whether the person is currently employed $\left(y_{\mathrm{i}}=1\right)$ or not $\left(y_{\mathrm{i}}=0\right)$. We estimate:

$P\left(y_{i}=1\right)=P\left(y_{i}^{*}>0\right)=P\left(x_{\mathrm{i}}^{\prime} \beta+\varepsilon_{\mathrm{i}}>0\right)=P\left(-\varepsilon_{\mathrm{i}} \leq x_{\mathrm{i}}^{\prime} \beta\right)=F\left(x_{\mathrm{i}}^{\prime} \beta\right)$

Where $F$ indicates distribution function of the erorrs (in case of logit, logistic distribution).

As can be derived from (1), in the logit model we have $\mathrm{P}\left(y_{\mathrm{i}}=1\right)=\frac{e^{x^{, \beta}}}{1+e^{\mathrm{x}, \beta}}$ so we can observe the marginal effect of $\beta_{k}$, i.e.:

$\frac{e^{x_{1}^{\prime} \beta}}{1+e^{x_{i} \beta}} \frac{1}{1+e^{x_{i} \beta}} \beta_{k}$
Due to the obvious influence of individuals characteristics in all regressors on the marginal effects, we also report much more accessible odds ratios, i.e. exponentiated coefficients.

\section{RESULTS AND DISCUSSION}

The estimation results are summarized in the following table (color coded by the signs of the coefficients, i.e. whether the given variable is increasing or decreasing the probability of being employed).

Survey data indicate that males are more likely to be participating on the job market, or alternatively, that a probability of females being employed in advanced age is about 0.67 times lower than with males. This corresponds with Eurostat employment statistics for active age population. The fact that the employed elderly are more likely to be men rather than women, corresponds to the findings of Balogová (2003) who says that retirement "leads to profound changes in the life situation, change of roles. In most cases, leaving a job does not lead to a reorientation but can cause a shock, especially in men." Increasing age decreases the probability of employment, while better health increases the probability of employment. Surprising fact, in particular contrasting "common knowledge" is that the financial situation (X100) is not statistically significant in explanation of the employment of the elderly which corresponds to the findings of, for example, Tickle (2008) or Barnes, Parry and Taylor (2004). If a person relies on social benefits, he or she is 0.64 times as likely to be employed (probably an indication of certain combination of problems as well). People living in regional capitals likely face wider job opportunities, which is reflected in their higher probability of being employed. Unsurprisingly, people who live in social homes are much less likely to be employed. Also, people who are in general content with their retirement do not seek employment as much, a similar thing can be said about people in marriage (base value), as other categories of X5 exhibit higher probability of employment then married people. The positive effect of volunteering supports the active ageing argument that people probably associated being active and job market participation. Positive effect of higher education supports the conclusions of Vidovicová (2008) who found that the people who are most looking forward to retirement are people with lower levels of education, while white collar workers and people with higher education most often consider retirement as unpleasant. The influence of education on the question of retention in the labor market is in line with conclusions in McNair (2006).

While Czech seniors were found to be rather non-homogenous (see in particular mind maps and results of the aforementioned Technology Agency of the Czech Republic, project No. TB05MPSV004-"Research in the quality of life of seniors in the Czech Republic" /"Výzkum v oblasti kvality života seniorů v ČR" (2016)), it seems that 
II: Logit model results, dependent variable X8A(Currently employed)

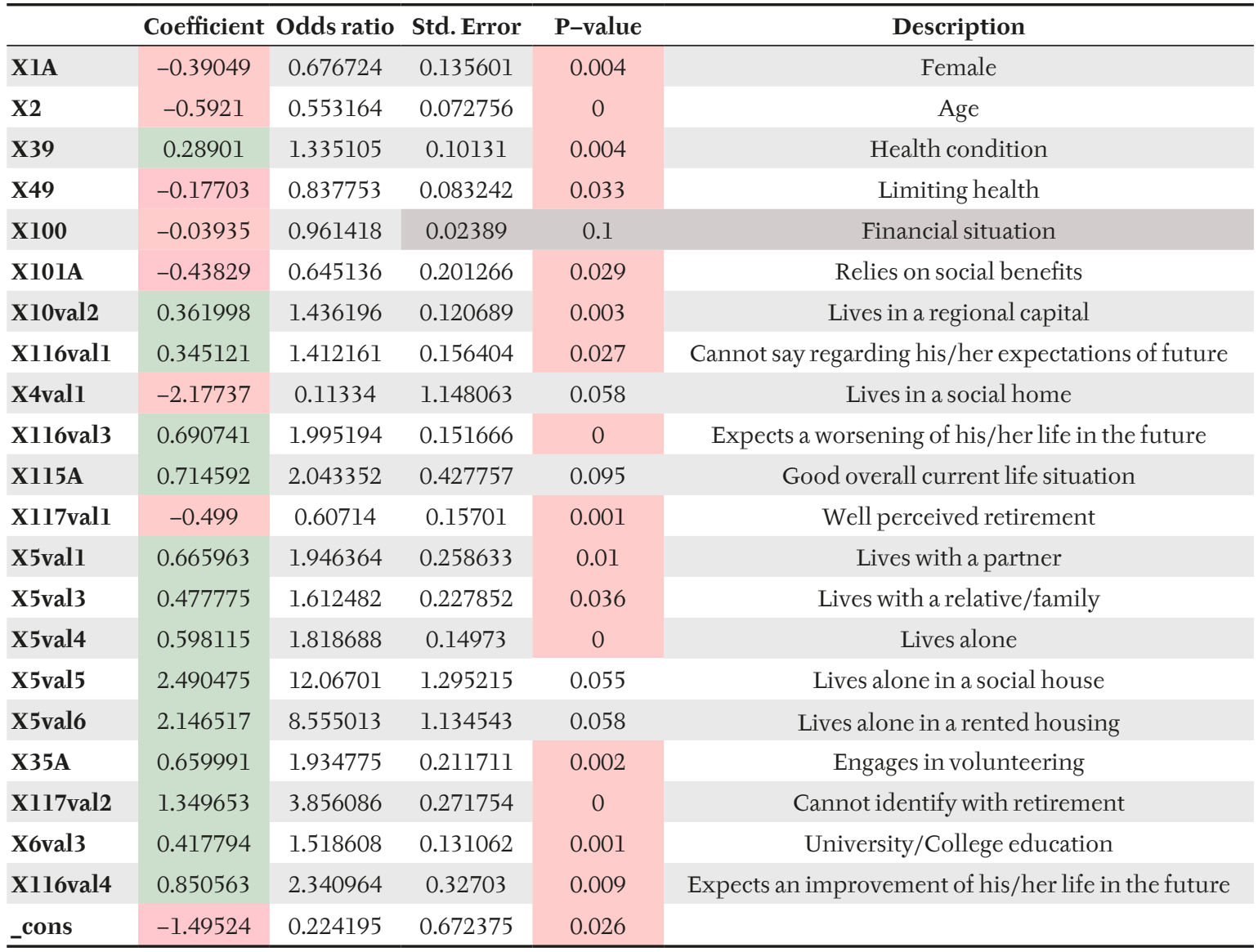

the main policy interest should not be concerned with income and social benefits, but rather with providing more stimulating environment for active work life and generating less obstacles for active elderly (documented e.g. by the heated debate following the changes in the taxation regime of Czech seniors working opportunistic part-time jobs).

\section{CONCLUSION}

In social policy, relatively low attention is paid to contrasting existing "self-evident" truths of paternalistic-minded policy makers with actual empirical observation.

Given the prospective development of demography in the Czech Republic, the active job market participation of elderly can be considered desirable for public budgets, in particular due to positive income effects, resulting in higher tax revenues (both due income tax and due to consumption - oriented taxes). Contrasting views might be arguing that the work participation of the elderly might be a necessity, rather than voluntary activity, implying the existing social scheme is distinctly underwhelming.

Hence the empirical investigation of the causes that motivate the elderly to be employed are of high interest and should be considered by social policy makers in particular.

While our results confirm several "common sense" expectations regarding age, health, gender or education effects on the employment of the elderly, we also find that so very often quoted arguments of unfavorable income conditions of the Czech seniors are not found to be influential for their propensity to stay in the labor market.

We also identify positive influence of volunteering on labor market participation (supporting one of the major active ageing arguments regarding multidimensional view of being active). Despite the fact that volunteering is much less popular in the Czech Republic than for instance in the United States, where agility and public engagement are not only uncommon, but perceived as evidence of vivacity, vigor and independence-in particular in the "white collar" job areas associated with higher intellectual demands. It seems that ageing phenomena are not simply associated with population being older, but also with changes of perceptions. Nowadays, the premarital periods of youth 
are extended with large tertiary education prevalence, associated with higher levels of individual independence. Yet, it seems that similar values and work-life balance are also important to the elderly, with "traditional" expectation of "stay-at-home" being challenged by additional work opportunities, higher levels of financial stability, and intellectual satisfaction associated with active ageing approach. Such "traditional" or "paternalistic" views also neglect to consider substantial amounts of human capital (such as education, work experience or simply life experience), that is being discarded by less than optimal conditions for their job market participation.

As our results show, an important proportion of the elderly are not only capable but also willing to engage in active ageing lifestyle. One important facet that is currently substantially under-researched is associated with a specific population group, represented by a number of people who lost their jobs late in their careers (close to the retirement age). Large percentage of those are unable to find a job afterwards, and instead opt to retire early. Under such conditions, retirement can be in a sense simply a contraindication of active ageing caused by problems residing in limited use of part-time contracts (or more likely with legal obstacles associated with part-time contracts). Such could continuously span over traditional retirement period and help not only lower the factual societal costs of unemployment of late-stage career workers but also to improve their general job and life satisfaction. It is thus of high importance to approach the ageing population not as cumbersome drain for public funds but as valuable resource.

Further research should in particular focus on the identification of efficient ageing management approaches regarding late stage labor market participants, in particular those engaged in job areas with lower physical demands (i.e. a range of "white collar" workers), who could most likely be associated with higher levels of human capital.

\section{Acknowledgements}

We are thankful for the support from the Technology Agency of the Czech Republic, project No. TB05MPSV004 -Research in the quality of life of seniors in the Czech Republic.

\section{REFERENCES}

BALOGOVÁ, B. 2003. Vstup do dochodku ako náročná životná situácia a kvalita života senior. In: SÝKOROVA, D. (Ed.). Senioři ve společnosti, Strategie zachování osobní autonomie. Boskovice: Nakladatelství František Šalé-Albert.

BARNES, H., PARRY J. and TAYLOR, R. 2004. Working after State Pension Age: Qualitative research. [Online] Available from: http://research.dwp.gov.uk/asd/asd5/rports2003-2004/rport208/Inside.pdf [Accessed: 2018, January 15].

BORSCH-SUPAN, A., BRANDT, M. HUNKLER, C. et al. 2013. Data Resource Profile: The Survey of Health, Ageing and Retirement in Europe (SHARE). International Journal of Epidemiology, 42(4): 992-1001.

BOUDINY, K. 2013. „Active ageing“: from empty rhetoric to effective policy tool. Ageing and Society, 33(6): 1077-1098.

BRADLEY, F. J. 2004. Active Aging and Self-Esteem. The Gerontologist, 44(5): 724-725.

ČEVELA, R., KALVACH, Z. and ČELEDOVÁ, L. 2012. Sociální gerontologie: úvod do problematiky. Praha: Grada.

EUROPEAN COMMISSION. 2015. Innovation Union: Active and Healthy Ageing. [Online]. Available from: http://ec.europa.eu/research/innovation-union/index_en.cfm?section=active-healthy-ageing\&pg= aboutWHO [Accessed: 2018, January 28].

HAŠKOVCOVÁ, H. 2010. Fenomén stárí. 2nd Edition. Praha: Havlíček Brain Team.

HOLCZEROVÁ, V. and DVOŘÁČKOVÁ, D. 2013. Volnočasové aktivity pro seniory. Praha: Grada Publishing, a.s. HOLMEROVÁ, I., JURAŠKOVÁ, B., ROKOSOVÁ, M., VAŇKOVÁ, P. and VELETA, P. 2006. Aktivní stárnutí. Česká geriatrická revue, 4(3): 163-168.

KŘIVOHLAVÝ, J. 2011. Stárnutí z pohledu pozitivní psychologie: možnosti, které čekají. $1^{\text {st }}$ Edition. Praha: Grada.

MARTIN, P., KELLY, N., KAHANA, B., KAHANA, E., WILLCOX, B. J., WILLCOX, C. and POON, L. W. 2015. The Gerontologist, 55(1): 14-25.

MCNAIR, S. 2006. How different is the Older Labour Market? Attitudes to Work and Retirement among Older People in Britain. Social Policy $\sigma$ Society, 5(4): 485-494.

MÜHLPACHR, P. 2004. Gerontopedagogika. $1^{\text {st }}$ Edition. Brno: Masarykova univerzita v Brně.

NOVOTNÝ, P., BOSNIČOVÁ, N., BŘENKOVÁ, J. et al. 2014. Age management: jak rozumét stárnutí a jak na néj reagovat: možnosti uplatnění age managementu $v$ České republice: prîvodce pro jednotlivce, organizace a společnost. Plzeň: Asociace institucí vzdělávání dospělých ČR.

OECD. 2015. Ageing: Debate the Issues. OECD Insights, Paris: OECD Publishing.

PISAREV, A. V. 2006. Factors of Employment in Retirement Age. Sociological Research, 45(1): 59-77.

TICKLE, L. 2008. But I don`t want to retire. Community Care, 1741: 16-17. 
VÁGNEROVÁ, M. 2007. Vývojová psychologie. Praha: Karolinum.

VIDOVIĆOVÁ, L. 2005. Věková diskriminace - ageismus: úvod do teorie a výskyt diskriminačních prístupư ve vybraných oblastech s dirrazem na pracovnitrh. Research Report. Praha, Brno: VÚPSV.

WALKER, A. 2002. A strategy for active ageing. International Social Security Review, 55(1): 121-129.

WORLD HEALTH ORGANISATION. 2002. Active Aging: A Policy Framework. WHO.

Lea Kubíčková: lea.kubickova@mendelu.cz 